\title{
Nature Of Certain Criminal Acts Against The Propperty Foreseen By Kosovo Legislation Overviewed By Material Target
}

\author{
Bahri Hyseni \\ bahri.hyseni@yahoo.com
}

\author{
DOI:10.5901/mjss.2014.v5n19p390
}

\begin{abstract}
Crimes against property in generally and in particular those directed against property represent a challenge to the country's economic development, the legal system in general, and the wealth of natural and legal persons. Kosovo and other countries also in the region, have given legal criminal protection to the public and private property, through criminal legislation and other legal acts. Therefore my definition in this paper is to analyze several offenses against property, with special emphasis against property, observed by material target. Nowadays there is no doubt that this group of offense. Cause to Kosovo's economy and its citizens millions of euros, which fact we actually support, often because, whether the property is either public or private, is attacked by the negligent actions of different persons, through arson, destruction of public installations, disposal, illegal occupation of real estate, actions that Kosovo Criminal Code of 2012, which is in power, has incriminated them as criminal offenses. From these criminal actions, are created illegal material benefits, which seriously harm the economy and create informal economy, harm legal competition, raise prices, and as a result of all this, is the damage caused to the state's economic development and social welfare in general. In this work, these criminal offenses will be treated by the material target also, the similarities that have with offenses against economy. At the end of the paper, i will analyze measures and penalties that the Kosovo criminal legislation provides for the perpetrators of these acts.
\end{abstract}

Keywords: Target material, penal code, criminal offenses, property, criminal sanction.

\section{General overview}

Criminal offenses as illegal acts, by which are violated, legal benefits protected by law, such as: human life, property, economy, freedom of movement, health, etc. in all criminal legislation, were given to them a legal -criminal protection. Kosovo criminal legislation has arranged these criminal offences in a special groups, however seeing the defense target of these criminal offenses, it is often difficult to make a complete separation between them. What makes these offenses not differ among themselves, are basic elements of criminal offense such as: Human action, its definition by law, illegality, guilt and punishment1. However, despite the common fundamental elements, that criminal offenses have, they have their own specifications by material target and material goods that they threat. Crimes against property have similarity with offenses against the economy, official duty or as provided in the Criminal Code of Kosovo in 2012, named "official corruption and criminal offenses against official duty"2. Criminal acts in general and especially those against property, are similar to other groups of offenses. This correlation exists for the fact that, they have common essential offense elements and the same defense target. For these reasons, difficulties emerge for lawmakers, to make a clear separation, and to arrange some of the offenses in the appropriate group. This difficulty is particularly pronounced for offenses against the economy and wealth. In this group of criminal offenses, target against whose is taken the unlawful action, Is the property of a natural or legal person and the purpose of perpetrators is unlawful acquisition of wealth.

Therefore there are hardly noticed differences between offenses against the economy and property. Therefore, there are differences present, at the persons who commit theese criminal offenses, where they are different, such as: Crimes against economy such as: causing bankruptcy, creditors damage or misuse of economic authorizations, can perform only those persons, who are responsible in business organization or legal persons. 3 While fraud as a crime against property4, which can be performed in the field of economic business, is committed by any person who brought himself or other unlawful property profit. Crimes against property and in the sphere of economy in some states, are foreseen only in one group such as: French Penal Code (1994), the Swiss Penal Code in Chapter Two, in the Albanian Criminal Code of 1995, in the third chapter. It is worth mentioning, that the majority of offenses against property and economy in the interim criminal code and the new criminal code of Kosovo of 2012, are foreseen in the Criminal Code of Albania of 1955. In my opinion some offenses found in the group of offenses against property in the Provisional Criminal Code such as: Fraud (Article 261), 
cheating on subsidies (Article 262), abuse of trust (neni269), smuggling of goods (Article 273), organized crime (Article 274)5, should take place in the group of offenses against the economy. It is worth mentioning that these offenses have remained in the framework of crimes against property in the new Criminal Code of Kosovo in 20126 . I also think that some offenses found in the group of offenses "Against the environment, animals, plants and cultural facilities" as destruction of forests (Article 357), theft of forest (neni358), illegal hunting (Article 359) as provided in the penal code of 20127 and 20048, should be systematized in the group of offenses against the economy, for the the fact that, they cause a great damage to the country's economy.

I think that the lawmaker, should make the separation of criminal offenses against economy and property, on the basis of unlawful activities and infringement of property. All illegal acts, directed against the economy, the financial system, customs and property of business entities, should have been incriminated in offenses against the economy, and actions directed against the wealth of natural persons, should be incriminated in the group of offenses against property. I think that the Kosovo lawmaker, has acted straight, when has removed, from the group of criminal offense against property, the offense Organized crime" (Article 283), placing it into a special group of criminal offenses9, because I believe that organized crime has its specifications in terms of organizing, structuring, to the legal goods that is addressed, and the consequences that brings for citizens and the state in general. The term "organized crime" is used for the first time during the year of 1986, in the report of Association for Crime Prevention in New York. The report, considered as organized crime, illegal businesses in which were included politicians, police officers, lawyers and professional thieves, where their crime was organized10. This dangerous form of crime, has abilities and premises, to appear in various social and economic activities, not only within states, but also internationally. Then such forms of criminality creates large capital, where then criminals through the capital, exert influence in the legal institutions, that may have consequences for the country11. Namely, for the fact that organized economic crime, poses great risk for damage of state and a serious threat to mankind, by which i consider that the Kosovo legislator, rightly has arranged this act, in a separate chapter in Kosovo's criminal code, and has drafted state strategy12, to combat this sophisticated form of crime in general and especially in the field of economy.

\section{Damages in the field of property from such offenses}

Property as a fundamental right, is protected by the Constitution of the Republic of Kosovo in Section 46 The first paragraph states "The right of property is guaranteed13. The economic system of the Republic of Kosovo is based on public and private property and the free market economy, This right is regulated by law, based on Article 121 of the Constitution of Kosovo. Criminal legal protection of property, regulates the Kosovo Criminal Code of 2013 in Chapter XXVII, in group of criminal offenses against the property14. Kosovo Constitution and our laws protect and secure property of individuals and foreign international organizations. According to the Kosovo Constitution Article 121, paragraph 2, states "Foreign individuals and foreign organizations in accordance with the law , can provide the right of ownership of immovable property, in compliance with reasonable conditions, prescribed by law and by international treaties15. Criminal legal protection of the property provides the Albanian Criminal Code too of 1995, in the third chapter, of the third section in the group of offenses against property and sphere of economy16. Protection of property is regulated also by international documents, European Convention on Human Rights in Article 1 Protocol supplement states: "Every natural or legal person has the right, his property to be respected, No one can be deprived of his property, except for the public interest reasons and in the conditions provided by law and the principles of international law17. So private property of natural persons, legal entities and state property due to the great economic importance that they have, enjoy protection by constitutional acts and legal acts, international acts and criminal legal protection, in the criminal codes of all states, of all criminal actions such as: theft, fraud, destruction etc. So these criminal acts directed against property, undoubtedly bring great losses and damage to the state's economy, legal and natural persons, therefore rightly Criminal Code of Kosovo and Albania, have foreseen criminal sanctions against perpetrators of these criminal acts. The main aim of the perpetrators of these acts, is generally acquisition of private or state property, and damage or destruction of property. So from this elaboration, we can understand that the goal of the perpetrators of these crimes, is material harm to the property - economy of state, and to natural and legal persons. Obviously in these criminal offenses, their figure changes, because, for example in the offense of stealing, perpetrator intends to obtain an unlawful material benefit for himself or for other, while at the damage or destruction of property, this intention does not exist. This category of criminal acts directed against property in the Penal Code of 2013, found in chapter offenses against property. A common group target of these acts is: Legal established relationships, to ensure the right of property as a fundamental right. 


\section{Nature of certain offenses related to property damage, target material orientated}

Offenses in the economy are a challenge and obstacle to the economic development of every country, especially of countries in transition, such as our country Kosovo. This group of acts, that are directed against the economic system and wealth of natural and legal persons, whose target is, a illegal enrichment and destruction of property through criminal actions. So the consequences of these criminal actions, batter material base of society, therefore it is fair to say, that these criminal offenses are an obstacle to the development of society18. The nature of each offense against the economy, has its special specifications of target material, but common specification of target material and criminal legal defense, are establishment of legal relations, for normal development of the economy, economic entrepreneurship, protection of property from damage etc. So the material target, of criminal offenses directed against property, are public or private property in general, Well it is important to have economic value, and simply not to be junk19. For some crimes against property damage, target material changes, for example criminal offense: "Destroying, damaging or removing public installations" provided for in section 366 of the Criminal Code of Kosovo in 2013, target of this crime are public equipment and installations that serve to fulfill the needs of citizens, so these installations are of a great importance for economic activity, and generally to people's lives, and their destruction may cause major disruption to citizens to get supplied with, water electricity, heating and with no doubt cause great economic damage, therefore this criminal offense can be considered as an offense against the economy20. Therefore destruction of these devices, causes endangering of life, body integrity and human health, or property on a large scale, therefore rightly, Kosovo Criminal Code of 2013, has foreseen this act, in the group of criminal offenses against the general safety and property, which means that the material target, is specific and differs from other acts, directed against the property.

Below we will present some crimes against property oriented by target - material

\subsection{Destruction or damage of property (Article 333)}

This offense carries anyone who damages, destroys or renders another person's property and makes it unusable in paragraph 1, the perpetrator shall be punished with imprisonment of up to (1) year. If the offense by this paragraph results in material damage exceeding $(5,000)$ euros, the perpetrator shall be punished with imprisonment from $(1$ to 3$)$ years. Under paragraph 3, qualified form of this offense is considered, if it is committed against the property or asset that has a cultural, religious, historical, value, it is of a special scientific, artistic importance, or it is protected part of a private or public collection, or it is a public item, that serves for the decoration of a square, street or park, where the perpetrator shall be punished by a fine and imprisonment of up to (3) years21. In the fourth paragraph is prescribed, the severe form of this offense, which is considered to exist if the property damage of the other is motivated by prejudice associated with ethnicity, nationality, religion, gender or language. This act has been envisaged in the Criminal Code of Kosovo in 2004 named "damage of moveable property "(Article 260)22. I believe that the current code has much better regulated the issue of legalcriminal defense of property from damage or destruction, for the the fact that it is not limited only to the moveable property, but also of immovable property, harmonizing it with criminal codes of neighboring states, such as Montenegro and BosniaHerzegovina, which also do not have restrictions only to movable property. I think that extending of protection toward the immovable property, is thoughtful because: for example, the house as a real estate may be destroyed by fire or other means.

Material target of crime of this criminal offense "destruction or damage of property", or as required by the Criminal Code of Albania, 1995 named "destruction or damage of property", where the property is private or public, and is sufficient for it to have a value, and it must be a matter of valuable items, to which can be caused damage, either in the content or appearance. So as it is understood, the property must be someone else's, but it can even be to another person. So the act of committing this criminal offense is defined alternatively when a perpetrator: a). only damages someone else's property, b) destroys it, c) makes it unusable23. The criminal offense it's considered to be committed, when someone's object or property is destroyed or made unusable.

Subject - the perpetrator of this crime can be any person who has reached the age of criminal responsibility and is accountable. From the objective side of view, the act is committed by unlawful act or omission. From subjective side, the offense is committed intentionally, which means that the perpetrator is aware, that is damaging or destroying property of other person. The criminal offense that we have treated, is provided in the Criminal Code of Kosovo of 2013, group of offenses "against property", where the Criminal Code of Kosovo SAP 1977, has also foreseen this offense named " damage of someone's object Article 145"24. Common subject of these acts is to bring material harm to natural persons, legal or state. However, these acts have substantial differences among themselves. For example, in the offense of theft, 
perpetrator has as intention, a illegal acquisition of someone else's assets for himself or other, at the damage of property that purpose lacks, where the perpetrator in general, causes great economic damage to the state or Persons. Therefore I consider that the Albanian Criminal Code of 1995 has much better adjusted the disposition of this offense, in the group of offenses against property and economic sphere, considering that property damage regardless of the manner of performance, cause severe damage either to state or private economy.

\subsection{Arson (Article 334)}

With the criminal offense of arson, we understand that anyone who alights or causes explosion with intent to damage property of another person, the perpetrator shall be punished by (6) months to (3) years 25 . From objective stand, the act is performed by omission, or active actions using dangerous tools for fire, to damage or destroy the property of another person, public and private property. What makes this act serious by the objective point of view is material damage caused to property or consequences caused to life and health of people. Penal Code, section 3 has provided that if the offense in paragraph 1 and 2, causing material damage in amount of $(20,000)$ euros or more, or causes to other serious body injury, the perpetrator shall be punished by (3) to ten (10) years26. With what has been proved, that this offense can cause great harm to the state's economy and natural persons, but this can also cause death of persons, so if this act results with the death of the person, the perpetrator shall be punished with at least (10) years imprisonment or life imprisonment27. Meanwhile Criminal Code of the Republic of Albania, has incriminated this act in Article 151 section three, stating that if the destruction or damage of property by fire is done intentionally, the perpetrator shall be punished by a fine or imprisonment of up to (5) years, and if from the criminal offense are caused significant material consequences, the perpetrator shall be punished up to this (10) years imprisonment, and when serious consequences are caused, for the life and health of people, the punishment of imprisonment will be imposed by (5) to (15) years28. This fact shows that the Republic of Kosovo in order to protect property, especially state and private economy, and particularly the health and lives of people, has provided very severe penalties, in serious cases, up to life imprisonment, where the consequences of this act resulted in the death of any person29. The subject of crime is any person who has the age of criminal responsibility and is accountable.

The nature of the material target is similar to the act that we have covered previously, wealth - public and private property in general, it is important to have economic value, and not be junk30. Criminal offense of arson, is foreseen for the first time in Kosovo criminal legislation in 2012, group of offenses against property, while neither the Kosovo criminal law of 1977, nor penal code of 2004, did not foreseen this offense. I consider that the state of Kosovo, through harsh punitive policy for this offense, has developed the prevention, that in case the perpetrators deliberately took action, in order that with fire damage, public or private property, or the life and health of people in general, be clear about the consequences that will be able to suffer.

\subsection{Destroying, damaging or removing of public installations (Article 366)}

The criminal offense that harms or destroys public or private property, that causes major economic damage in general to population, and to state economy is: "Destroying, damaging or removing public installations" (Article 366)". This act is performed by damaging or destroying electrical conductors, gas, water installations, heating, telecommunications equipment, feathers, and other similar devices. Therefore the Criminal Code: Destruction or damage of this equipment by anyone, when there are caused disturbance of supplement to the population or economy, has incriminated it by foreseeing imprisonment of up to (5) years31. But if criminal offense of , destruction or removal of these devices, causes a great threat to life, body integrity and health of people, or their property on a large scale in general, in paragraph 3 is provided: prison sentence (1) through (8) years32, while the fourth paragraph provides that: "If the criminal offense under paragraph 1 of this Article results in death of one or more persons, the perpetrator will be sentenced to imprison from (3) to (12) years33. So incrimination goal is to protect public installations, in order to supply the population with no obstacles for normal life and development of their economy.

Material target, of this offense are: aforementioned public equipment and installations, which serve to fulfill the needs of citizens, and to carry out various economic activities34. While according to prof. Ismet Elezi on the special part of criminal law, material target of criminal offense, "Destruction of electrical network" as named in the criminal code of Albania are: Cables, transformers, telephone and electric cables, private and public property. Perpetrator of this crime is any person, who has reached the age of criminal responsibility and is accountable. Regarding the way of performing of this offense, it is alternative and it's manifested by removing these installations, by destroying, damaging or make them unusable. As for the guilt concern, this offense can be committed intentionally and negligently. Regarding the criminal sanction, it can be 
with fine and imprisonment. Serious form of this offense is considered, when has resulted with serious body injury, or substantial property damage, where the offender can be sentenced up to (8) years in prison, and if results with death of one or more persons, the perpetrator shall be punished from (3) to (12) years. If we compare the punitive policy for this offense with the same material target, but with different label, under the criminal code of Albania, it is punishable by a fine and imprisonment of up to (3) years. It is worth noting that this code, has provided a total of 13 offenses against property destruction, in section three in the group of offenses against property, and in the sphere of economy. By my opinion, the criminal code of Albania of 1995, has specifically and in detail arranged these acts. This offense has been envisaged in the Provisional Criminal Code of Kosovo in Section 292, the same content, label and criminal sanction35. The criminal law of Kosovo of 1977 Kosovo, has foreseen this offense too, but has provided only its basic form in paragraph 1 of Article 158, which predicts that whoever destroys, damages or makes unusable installations of public use, and causes considerable disturbance in the lives of ordinary citizens, shall be punished from (6) months to (5) years in prison, and if the offense is committed by negligence the perpetrator shall be punished with imprisonment up to (3) years36. Finally we can say that the penal code of 2004 and that of 2013, have provided for this offense, the qualified and basic form, whereas the criminal law of SAPK, only regulated the basic form, whereas the Albania's penal code, has split this criminal offense, the into several offenses such as: destruction of the electric grid (Article 156), destruction of irrigation network (Article 157), the destruction of water supply (159) etc.

\section{Conclusion}

Crimes against property, with special emphasis in the area of property, represent a great loss not only to public property but also private one. Offenses discussed in this paper, are steadily increasing and present danger to the economic system in Kosovo, especially affecting in the growth of organized crime in general. The main purpose of the perpetrators of these criminal offenses in general, is appropriation of public or private property, damage or destruction of property. In this paper, by study is concluded that the purpose of the perpetrators of these criminal acts is to bring to the state economy, property - material damage, and to the legal and natural persons. Material target of criminal acts directed against property, are public and private property. By treating material target of some criminal offenses, "Destroying, damaging or removing public installations", as envisaged in Article 366 in the Penal Code of 2013, Shows that the object of this crime are public equipment and installations that serve to meet the needs of citizens, so these installations are of great importance for economic activity and in general for human life's. Their destruction could cause major disruption, on supplying of people with water, electricity, heating, and undoubtedly causes great economic damage, therefore this offense can be considered as a criminal offense against the economy. Thus destruction of these devices, causes endangering of life, body integrity and health of people or property on a large scale. Therefore Kosovo Criminal Code of 2012, rightly has foreseen this offense, in the group of offenses against the general safety and property. Target material at offenses against property, is specific and differs from other criminal acts, and property in general should be of economic value, so not simply being junk. By this we can conclude, that people could every day be victims of such offenses as: arson, destruction or damage of property, destruction, damage or removal of public installations, therefore the state of Kosovo must consistently convey this kind of criminality, in order to create legislation that will not be operational as a pre action and nod after action in relation to its development trends. I consider the state of Kosovo through the development of appropriate legislation and harsh punitive policy for such offenses, has made prevention, that in case if the offender intentionally takes action, to damage public or private property by fire, or the life and health of people in general, be clear about the consequences that will be able to suffer. Kosovo needs deep reforms in the judiciary to combat this type of crime, judges and prosecutors should be specialized in different areas of the economy, should be provided, experts who will work in support of the prosecution bodies, should be created databases, for providing data for potential criminal cases. Finally I think, that official records that the bodies of justice possess, for the number of criminal offenses in property, are not realistic in relation to offenses carried out in practice, but unfortunately they remain undiscovered or not declared at all.

\section{Lit e r a t u re}

Demolli Haki, "Economic Crime in Kosovo in year of eighties", Pristina, 2009

Ismet Elezi, "The Criminal Law (CC), Tirana, 2009

Ismet Salihu, "Criminal Law" (CC), Pristina, 2009

Ragip Halili Some works of organized crime in Kosovo, law no. 4

Vlado Kambovski, Criminal general part, Skopje, 2010 
Veto Vula, Organised Crime, the European College "Dukagjini", Prishtina 2013

Vesel Latifi, Criminology, Pristina, 2006

See Penal Code of 2012.

See: Provisional Criminal Code of Kosovo, 2004

See Criminal Law of the SFRY, the year 1977.

See: Criminal Law's Gazette, 1977

The Constitution of the Republic of Kosovo, 15. June 2008

13. The European Convention of Human Rights and Fundamental Freedoms signed in Rome on 4 November 195013.

See: National Strategy of the Republic of Kosovo, organized crime and action plan 2009-2012

\section{References}

1.Vlado Kambovski, Criminal Law, general part, Skopje, 2010, p. 125

2.See Criminal Code of Kosovo, Chapter XXXIV

3.Ismet Salihu, Criminal Law special part, Fama College Pristina 2009, p. 298

4.See: Provisional Criminal Code of Kosovo of 2004, Section, 261

5.Ibid Chapter XXIII

6.See: Criminal Code of Kosovo, Chapter XXVII

7.Ibid Chapter XXVIII

8.Provisional Criminal Code of Kosovo, promulgated by UNMIK Regulation no. 2003/25 of dt. 6 July 2003 and empowered on April 6, 2004, Chapter XXIV

9.See Kosovo Criminal Code, Chapter XXIV

10.Veton Vula, Organised Crime, the European College "Dukagjini", Prishtina 2013, p. 23

11.Ragip Halili Some acts of organized crime in Kosovo, law no. 4

12.See: National Strategy of the Republic of Kosovo, against the organized crime and action plan 2009-2012

13.The Constitution of the Republic of Kosovo, 15. June 2008, Article 46

14.See Chapter XXVII of the Criminal Code of 2013

15.See Constitution of Republic of Kosovo, Article 121, paragraph 2

16.See Chapter III of the Criminal Code of Albania approved by Law no. 7895, dated 27.01.1995 and amended in 1977.2008 and 2001

17.European Convention of Human Rights and Fundamental Freedoms signed in Rome on 4 November 1950

18. Vesel Latifi, Criminology, Pristina, 2006, p. 326

19. Ismet Elezi, Criminal Law (Special part), Tirana, 2009, p. 254

20. Ismet Salihu criminal law (Special part), Pristina, 2009, pp. .408-409

21. See Criminal Code of 2013, Section 333

22. See the Provisional Criminal Code of Kosovo of 2004

23. Ismet Salihu criminal law (CC), Pristina, 2009, p q. 352-353

24. See Criminal Code of the Socialist Autonomous Province of Kosovo of 1977 